\title{
Rainwater Chemistry and Wet Deposition over the Wet Savanna Ecosystem of Lamto (Côte d'Ivoire)
}

\author{
V. YOBOUÉ ${ }^{1}$, C. GALY-LACAUX ${ }^{2}$, J. P. LACAUX ${ }^{2}$ and S. SILUÉ ${ }^{1}$ \\ ${ }^{1}$ Laboratoire de Physique de l'Atmosphère, Université de Cocody, 22 BP 582, Abidjan 22 \\ (Côte d'Ivoire),e-mail: yobouev@hotmail.com \\ ${ }^{2}$ Laboratoire d'Aérologie, 14 Av. Edouard Belin, 31400 Toulouse, France, \\ e-mail:lacc@aero.obs-mip.fr
}

(Received: 7 July 2004; accepted: 23 June 2005)

\begin{abstract}
From the IGAC-DEBITS Africa network (IDAF), data sets on precipitation chemistry collected from the 'wet savanna ecosystem' site of Lamto (Côte d'Ivoire), are analyzed (1995-2002). Inorganic $\left(\mathrm{Ca}^{2+}, \mathrm{Mg}^{2+}, \mathrm{Na}^{+}, \mathrm{K}^{+}, \mathrm{NH}_{4}^{+}, \mathrm{Cl}^{-}, \mathrm{SO}_{4}^{2-}, \mathrm{NO}_{3}^{-}\right)$and organic $\left(\mathrm{HCOO}^{-}, \mathrm{CH}_{3} \mathrm{COO}^{-}\right)$ions content were determined using Ion Chromatography. The analyzed 631 rainfall events represent $8420.9 \mathrm{~mm}$ of rainfall from a $9631.1 \mathrm{~mm}$ total. The precipitation chemistry at Lamto is influenced by four main sources: natural biogenic emissions from savanna soils $\left(\mathrm{NO}_{x}\right.$ and $\left.\mathrm{NH}_{3}\right)$, biomass burning (savanna and domestic fires), terrigeneous particles emissions from dry savanna soils, and marine compounds embedded in the summer monsoon. The inter-annual variability of the weighted volume mean concentration of chemical species linked with wet deposition fluctuates by $\sim 20 \%$ over the period. Ammonium concentration is found to be the highest $\left(17.6 \mu\right.$ eq. $\left.1^{-1}\right)$ from all IDAF sites belonging to the West Africa ecosystems. Ammonia sources are from domestic animals, fertilizers and biomass burning. In spite of the high potential acidity of $30.5 \mu$ eq. $1^{-1}$ from $\mathrm{NO}_{3}^{-}, \mathrm{SO}_{4}^{2-}, \mathrm{HCOO}^{-}$ and $\mathrm{CH}_{3} \mathrm{COO}^{-}$, a relatively weak acidity is measured: $6.9 \mu$ eq. $1^{-1}$. The $40 \%$ acid neutralization is explained by the acid gas - alkaline soil particles interaction. The remaining neutralization is from inclusion of gaseous ammonia. When results from Lamto, are compared with those from Banizoumbou (dry savanna) and Zoetele (equatorial forest), a regional view for wet tropospheric chemistry processes is obtained. The high concentration of the particulate phase in precipitation emphasizes the importance of multiphases processes between gases and particles in the atmospheric chemistry of the West Africa ecosystems. For example, the nss $\mathrm{Ca}^{2+}$ precipitation content, main indicator of terrigeneous particles, goes from $30.8 \mu$ eq. $1^{-1}$ in dry savanna to $9.2 \mu$ eq. $1^{-1}$ at Lamto and $8.9 \mu$ eq. $1^{-1}$ in the Cameroon forest. A similar gradient is obtained for rainfall mineral particles precipitation content with contribution of $80 \%$ in dry savanna, $40 \%$ in wet savanna, and $20 \%$ in the equatorial forest.
\end{abstract}

Key words: precipitation chemistry, African wet savanna, wet deposition, acid rain, heterogeneous chemistry

\section{Introduction}

During the last decade, within the framework of the International Global Atmospheric Chemistry (IGAC) programme, the tropics have been considered as a key region regarding global atmospheric chemistry (IGAC, 2003). Due to intense ultraviolet radiation and high water-vapor pressure, high $[\mathrm{OH}]$ radicals concentration 
oxidizes inorganic and organic gases, and triggers removal of oxidized products from the atmosphere. Deep convection in the tropics results in processing and transporting large volumes of air masses loaded with gases and particles emitted by ecosystems. Knowledge of rainfall chemical composition, signature of the capture of gases and particles by cloud droplets and raindrops, allows to track emissions within rainfall events, their seasonal and interannual variability as well as trends and atmospheric chemistry processes. Wet-deposition studies are essential for understanding the key mechanisms controlling the overall atmospheric chemical content and to determining the nutrient imput or toxic impact for the biological functioning of the ecosystems.

From IGAC, the Deposition of Biogeochemically Important Traces (DEBITS) international project started in 1990. Syntheses of main results are available in IGAC Newsletters 27 and 28 (2003). The DEBITS scientific objectives have been:

- to determine, at the regional scale, the atmospheric removal rates of biogeochemically important trace species, by dry and wet depositions;

- to evaluate atmospheric budgets of key elements $(\mathrm{S}, \mathrm{N}, \mathrm{Ca}, \mathrm{C} 1 \ldots$ ) at the regional scale;

- to establish the chemical and physical factors that modulate these deposition fluxes;

- to develop parameterization for integration into regional and global atmospheric chemistry models.

To fulfil these objectives, the DEBITS scientific committee defined a set of experimental and analytical protocols to insure data quality, and permit inter-comparison of measurements from wet and dry deposits for all DEBITS stations. During the first half of 2004, fifty DEBITS measuring sites were activated in the tropical belt.

Concerning tropical Africa, the IGAC/DEBITS/Africa project or IDAF, started in 1994. The major objectives of IDAF were to measure wet and dry deposition fluxes, to identify the relative contribution of natural and anthropogenic sources and factors regulating these fluxes. The above objectives were attained at 10 specific sites (Figure 1). Six "paired sites" monitor three types of ecosystems over west and central Africa: dry savanna (Niger and Mali), wet savanna (Côte d'Ivoire and Central Republic of Africa), and equatorial forest (Congo and Cameroon).

As a part of IDA program, studies have been conducted for two of these regional ecosystems: dry savanna (Banizoumbou, Niger, see Galy-Lacaux and Modi, 1998) and rain forest (Zoetele, Cameroon, see Sigha et al., 2003). These studies pointed out that the chemical composition of rainwater in each ecosystem present specific characteristics. They are linked to numerous factors such as the atmospheric emissions, meteorological parameters like rain amount, rain intensity, wind direction and velocity linked to seasonal variability. Table I indicates the major gases and particles emissions for the meridian transect: dry savanna-wet savanna-equatorial forest, during dry- and wet-seasons, associated with precipitation and their chemical signatures measured in the IDAF network. The incoming sources from dry 


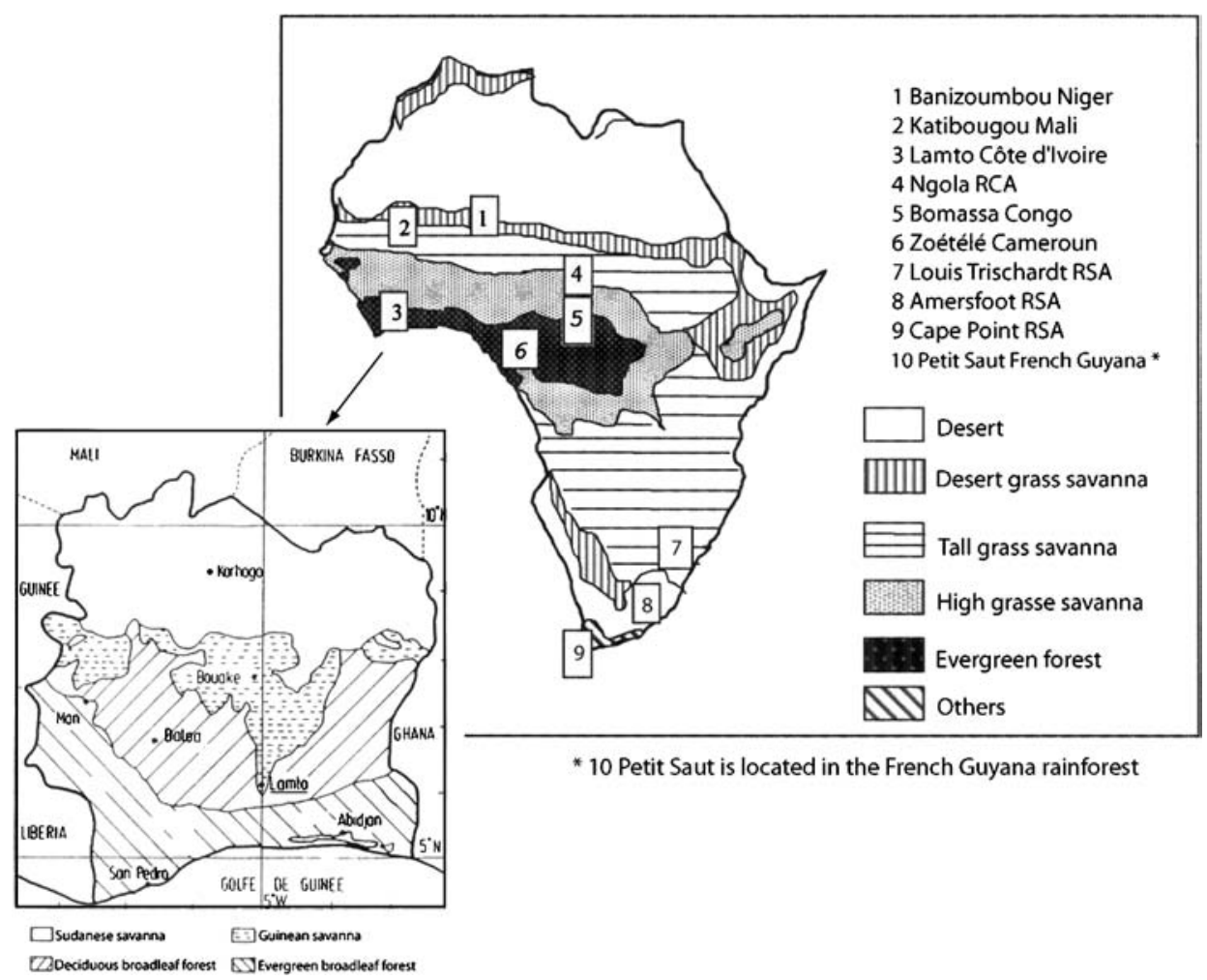

Figure 1. Vegetation and localization map of the IDAF sites with vegetation and localization of the Lamto site in Côte d'Ivoire.

savanna are mainly terrigeneous and nitrogen oxides respectively, linked to soils emissions and to ammoniacal emissions from domestic animals. In wet savanna, major emissions are from biomass burning, soils, vegetation and domestic animals. For forested ecosystems major sources are from vegetation and soils.

Using the precipitation chemistry database, collected at Lamto representative of wet savanna ecosystems (January 1995 to December 2002), the objectives were to:

determine the interannual variability and trend of the rainwater chemical composition and wet deposition;

determine the main annual chemical composition of precipitation and associated wet deposition, in relation with sources of gases and particles. Compare this chemical composition with that of three IDAF sites, representative of dry savanna and forest;

analyze the mean seasonal chemical composition of precipitation and to identify the atmospheric sources functioning during dry and wet seasons;

to analyze the relative contribution of mineral particulate and gas phases in precipitation to highlight the role of heterogeneous processes; and

to study the precipitation acidity over of the western-african ecosystems. 


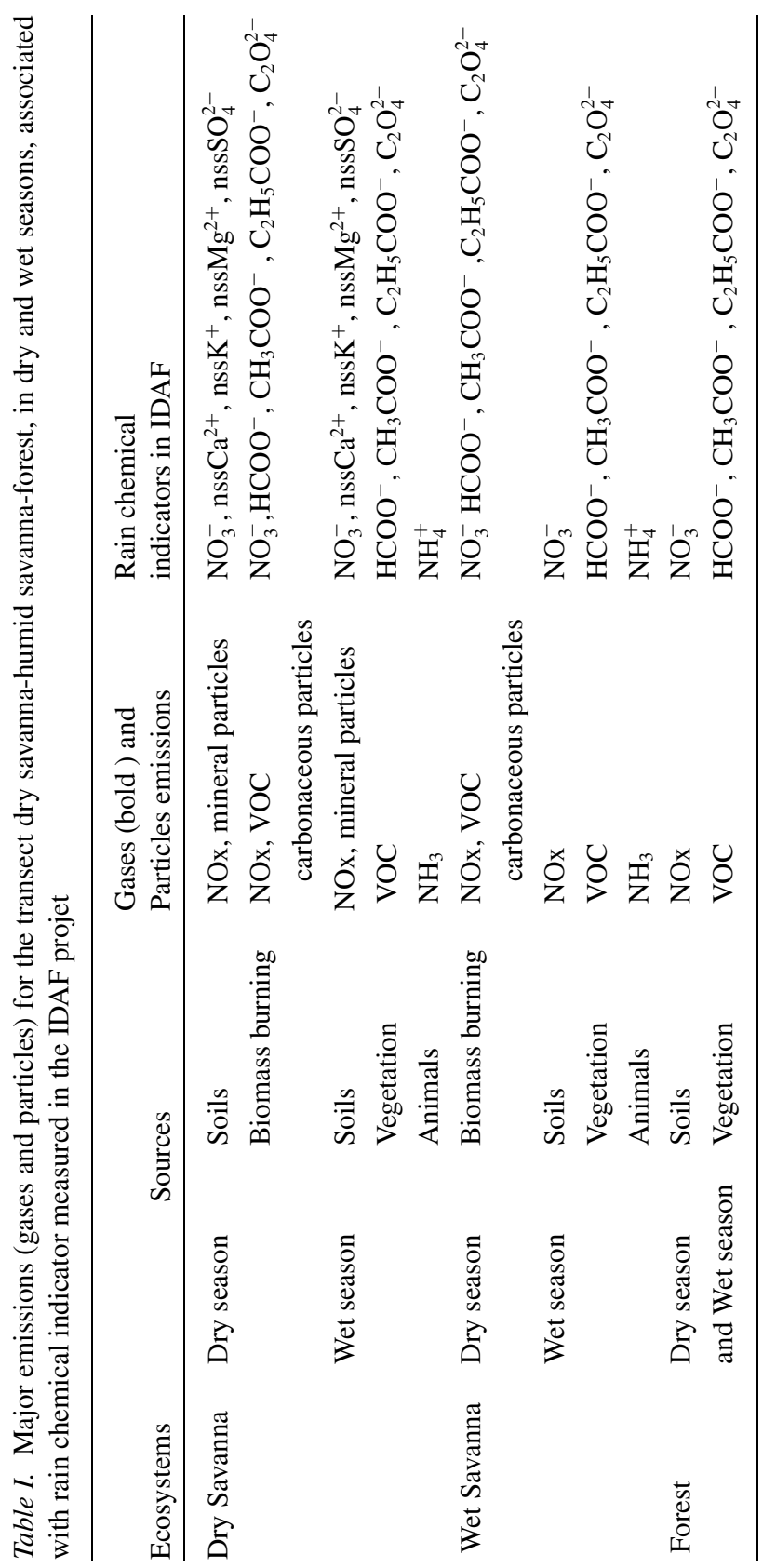


Results presented here are to complete the assessment on wet deposition along the transect dry savanna-wet savanna-rain forest and to evaluate large scale tropospheric chemistry mechanisms, as already proposed by Galy-Lacaux and Modi (1998) and Sigha et al. (2003).

\section{Experimental Design}

The Lamto geophysical and ecological monitoring station has been activated in 1960 by Professors Lamotte and Tournier (hence the name of Lamto). For the last four decades, seismological, ecological and climatological data from this natural reserve have been compiled. They have been analyzed by international and African scientific communities, with results used as a reference for a 'wet savanna' environment. During 1994, the international program DEBITS/IDAF, included this site in its network, and build up results from already existing studies on atmospheric chemistry (Servant et al., 1984; Baudet et al., 1990; Yoboué, 1991; Delmas et al., 1987; DECAFE Special Issue, 1991).

\subsection{THE LAMTO SITE AND ITS METEOROLOGICAL CONDITIONS}

Lamto is located, in the "V-shaped Baoulé" region (120 km north of Abidjan) at $6^{\circ} \mathrm{N}$ and $5^{\circ} \mathrm{W}$. The average altitude is of $105 \mathrm{~m}$, and it belongs to the wet savanna region of Côte d'Ivoire (Figure 1). The Lamto Reserve covers approximately 2600 ha and is constituted essentially of wet savanna with the, so-called, Gallery Forest along the Bandama river (Gautier, 1990).

The atmospheric chemical composition is influenced by emissions from the wet savanna modulated by local, regional and global processes. Local perturbations are mainly anthropogenic from coffee-cacao fields, from agro-industrial activities linked to pine-apple farming and domestic fires from small villages. At the regional and global scales, emissions are modified and transported by the summer monsoon and harmattan flows.

In general, the West African climate (and its variability) is a function of the position of the Intertropical Convergence Zone (ITCZ), the frontier between cool and humid marine air mass (monsoon) and warm and dry saharan air mass (Harmattan). Extreme latitudinal positions of the ITCZ are in January $\left(\sim 5^{\circ} \mathrm{N}\right)$ and August $\left(\sim 22^{\circ} \mathrm{N}\right)$. Kouadio (2002) has characterized the climatology of the Côte d'Ivoire in three climatic zones (from north to south): the sahelian dry zone, the forested savanna, and the degraded forested zone. Lamto, is located in the central zone with forested wet savanna. Over Côte d'Ivoire, annual precipitation amount vary from $700 \mathrm{~mm}$ (extreme North-East), to $1700 \mathrm{~mm}$ (South-Southeast).

The central region of Lamto, display a rainfall seasonal cycle with a bimodal structure characterized by four periods: two rainy seasons separated by a long dry season during December-February and a short dry season in August. The duration of the dry seasons is highly variable. During the dry season, Lamto is located 


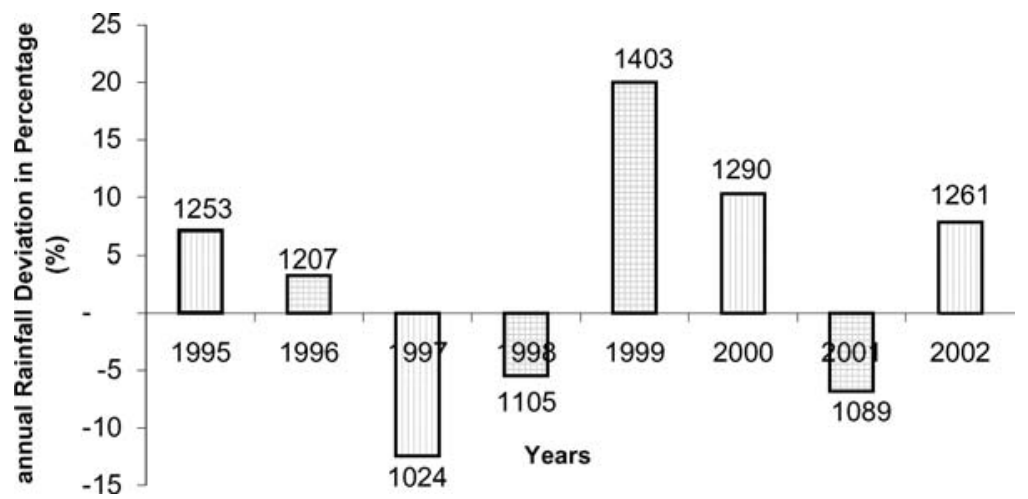

Figure 2. Interannual variability of precipitation at Lamto in $\%$, calculated from the deviation of annual precipitation to the mean annual rainfall for the $1965-2000$ period (1169 mm). Annual rainfall in $\mathrm{mm}$ is indicated on the bar.

to the North of ITCZ and is directly influenced by the continental air masses (or Harmattan) which contain terrigeneous particles and chemical species from savanna fires. During the wet season, from March/April to October, Lamto is now located to the south of ITCZ, under the influence of cool and humid maritime air masses, loaded with marine aerosols. During this period, the biogenic sources of the wet savanna ecosystem are extremely active. Moreover, the summer monsoon layer thickness and water-vapor availability allow for deep atmospheric convection.

The mean annual rainfall amount is of $1169 \mathrm{~mm}$ (1965-2000). During the period under study (1995-2002), a minimum of $1027 \mathrm{~mm}$ is observed in 1997 with a mean deviation of $12 \%$, and a maximum of $1402 \mathrm{~mm}$ in 1999 with a mean deviation of $20 \%$ (see Figure 2).

In Table II, the yearly main characteristics for the dry and wet seasons distributions are displayed. Dry seasons last for 2 to 5 months with rainfall amount from $16.1 \mathrm{~mm}(1995 / 1996)$ to $222.4 \mathrm{~mm}(1999 / 2000)$. The mean dry season rainfall is of $96 \mathrm{~mm}$ which represent $8 \%$ of rainfall events (70\% of rainfall events produce less than $10 \mathrm{~mm}$ of rain). Wet seasons last for 7 to 9 months, with an average rainfall amount of $1108 \mathrm{~mm}$ (54\% of rainfall events produce less than $10 \mathrm{~mm}$ of rain). The two seasons, as defined, will be used to study the mean seasonal characteristics of the rain chemical composition and wet deposition.

\subsection{MEASURING PROCEDURES, CHEMICAL ANALYSES AND DATA QUALITY}

A brief description of experimental techniques is presented here (for further details see Galy-Lacaux and Modi, 1998; Sigha et al., 2003; Mphepya et al., 2003). Additional information can also be obtained from the IDAF Web Site: http://medias.obsmip/idaf/ 
Table II. Yearly main characteristics for the dry and wet season distribution for the experimental period

\begin{tabular}{|c|c|c|c|c|c|c|c|c|}
\hline & 1995 & 1996 & 1997 & 1998 & 1999 & 2000 & 2001 & 2002 \\
\hline January & \multirow[t]{2}{*}{$13.2 \mathrm{~mm}$} & 11.0 & 51.2 & 68.4 & 190.0 & 171.8 & 17.7 & 52.8 \\
\hline February & & \multirow{9}{*}{1167.1} & \multirow{10}{*}{972.4} & & & & & \\
\hline March & \multirow{9}{*}{$\begin{array}{c}1234.4 \\
\mathrm{~mm}\end{array}$} & & & & & & & \\
\hline April & & & & & & & & \\
\hline May & & & & 1036.9 & 1162.3 & 1067.0 & 1021.9 & 1199.6 \\
\hline June & & & & & & & & \\
\hline July & & & & & & & & \\
\hline August & & & & & & & & \\
\hline September & & & & & & & & \\
\hline October & & & & & & & & \\
\hline November & & \multirow[b]{2}{*}{28.8} & & & & & & \\
\hline December & $5.1 \mathrm{~mm}$ & & 0.0 & & 50.6 & 51.0 & 49.8 & 8.1 \\
\hline
\end{tabular}

Dry Season

Wet Season

\subsubsection{Measuring Procedures}

Rainwater samples were collected on rainfall event basis, with an automated 'wetonly' sampler of $225 \mathrm{~cm}^{2}$, built for the DEBITS/IDAF network. At the end of each event, rainwater is collected in a Greiner $50 \mathrm{ml}$ sampling tube. The samples are stored in a deep freeze environment, thus avoiding microbial activities and possible alteration of chemical composition. A total of 631 events, representing a total rainfall amount of $8420.9 \mathrm{~mm}$, have been sampled during the period under study (see Table III). The total rainfall amount during the eightyear monitoring is equal to $9631.1 \mathrm{~mm}$. In Table III, the efficiency collection is given year-by-year with a range from $68 \%$ to $94 \%$ and a mean of $87 \%$. The

Table III. Rainwater collection in Lamto (1995-2002): Annual rainfall (H in $\mathrm{mm})$, number of collected events $(\mathrm{N})$, collected rainfall depth $(\mathrm{Hc}$ in $\mathrm{mm})$ ) and Efficiency Collection (EC in \%)

\begin{tabular}{llrrr}
\hline Year & $\mathrm{H}$ & $\mathrm{N}$ & $\mathrm{Hc}$ & $\mathrm{EC}$ \\
\hline 1995 & 1252.7 & 61 & 852.8 & 68 \\
1996 & 1206.9 & 78 & 971.1 & 80 \\
1997 & 1023.6 & 75 & 945.5 & 92 \\
1998 & 1105.1 & 76 & 1001.4 & 91 \\
1999 & 1402.9 & 88 & 1260.4 & 90 \\
2000 & 1289.8 & 84 & 1211.5 & 94 \\
2001 & 1089.4 & 74 & 989.0 & 91 \\
2002 & 1260.5 & 95 & 1189.2 & 94 \\
Total & 9631.1 & 631 & 8420.9 & \\
Mean & 1203.9 & 79 & 1052.9 & 87 \\
\hline
\end{tabular}


sampling efficiency is then well representative of precipitation regime at the Lamto site.

\subsubsection{Chemical Analyses}

The presence of dissolved ions was determined by using ion chromatography at the IDAF laboratory in Toulouse. The ion chromatography system used, as well as the main characteristics of the analytical parameters for the determination of mineral ions $\left(\mathrm{Ca}^{2+}, \mathrm{Mg}^{2+}, \mathrm{Na}^{+}, \mathrm{K}^{+}, \mathrm{NH}_{4}^{+}, \mathrm{Cl}^{-}, \mathrm{SO}_{4}^{2-}, \mathrm{NO}_{3}^{-}\right)$, and organic ions $\left(\mathrm{HCOO}^{-}\right.$, $\mathrm{CH}_{3} \mathrm{COO}^{-}$), are detailed in Galy and Modi (1998). The analytical precision for all the ions is $5 \%$ or better. $\mathrm{H}^{+}$was calculated from the $\mathrm{pH}$ measurements using an ATI Orion 350 instrument with a combined electrode (ATI Orion model 9252) filled with $\mathrm{KCl}(4 \mathrm{M})$ and satured with $\mathrm{AgCl}$. Two standard solutions (WTW) at $\mathrm{pH} 4.01$ and 7.00 are used for its calibration. From the $\mathrm{pH}$ values, $\mathrm{H}^{+}$ions concentrations are calculated. The precision is of $0.01 \mathrm{pH}$ unit.

\subsubsection{Data Quality}

At first, all the chemical analyses are doubled-checked through inter-laboratory comparison tests, organized annually by the World Meteorological Organisation (WMO) (http://marble.asrc.cestm.albany.edu/qasac/lab_ic.html). Secondly, the quality control for the entire database is checked for each rain sample by calculating the ionic balance test following Sigha et al. (2003). Computations are based on the 'percent ion balance criteria', as described by WMO (EPA, 1994). We applied these criteria to the 8-year samples in Lamto, and only data that passed the WMO specifications were used in the study. From 1995 to 2002 the range of WMO certified samples is between 88 to $100 \%$. Over the eight years, $97 \%$ of the total samples passed the WMO criteria and were used here. Finally, after applying all the quality control procedures, we use a total rainfall amount of $8268.1 \mathrm{~mm}$ from an overall amount of $9631.1 \mathrm{~mm}$ (i.e., $86 \%$ corresponding to the 615 samples).

\section{Chemical Composition of Rainwater and Wet Deposition}

In this section, we study the interannual trends of the chemical composition of precipitation and wet deposition on 8 years of measurements. Then, we determine the mean annual chemical composition of precipitation and the associated wet deposition using the 8 years of measurements. This is to provide the precipitation chemistry characteristics of an african wet savanna ecosystem. The mean composition is compared to three IDAF sites, representatives of the semi arid savanna and forested ecosystems, in relation with the associated sources of gaseous and particulate species that determine the chemical precipitation content. Finally, we present the mean seasonal chemical composition of precipitation to estimate the 

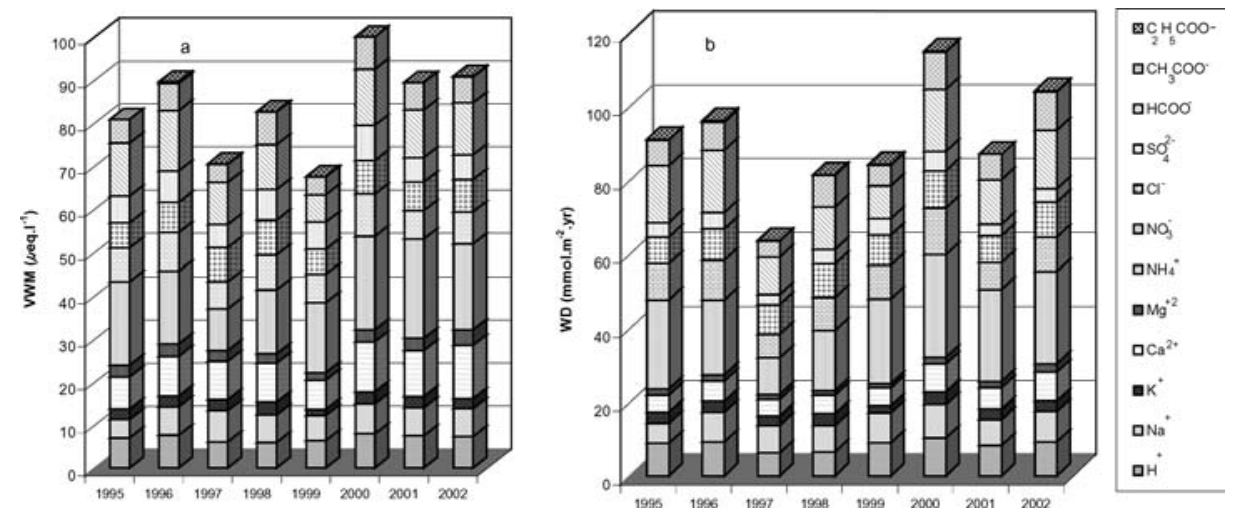

Figure 3. (a) Annual average volume weighted mean concentration $\left(\mu\right.$ eq. $\left.1^{-1}\right)$ in rainwater for the eight years (1995-2002) at the wet savanna site of Lamto and (b) Annual wet deposition (mmol.m $\left.\mathrm{m}^{-2} \mathrm{yr}^{-1}\right)$.

relative contribution to the annual VWM concentrations and to the wet deposition fluxes.

\subsection{INTERANNUAL VARIABILITY}

The volume-weighted mean (VWM) concentrations of ionic constituents in rainwater from Lamto station have been calculated by using the following equation:

$$
\operatorname{VWM}\left(\mu \text { eq. } \mathrm{l}^{-1}\right)=\sum_{i=1}^{n=615} C_{i} P_{i} / \sum_{i=1}^{n=615} P_{i}
$$

$C_{i}$ the ion concentration for each species in $\mu$ eq. $1^{-1}, P_{i}$ the precipitation amount for each rainy event in $\mathrm{mm}$. The Wet Deposition (WD) has been calculated by using:

$\mathrm{WD}=\mathrm{VWM} \times P$ with VWM being the Volume Weighted Mean concentration for each species and $P$ the mean rainfall amount measured during the studied period.

In Figures 3(a and b), annual weighed volume mean concentration and wet deposition fluxes year by year for precipitation, are displayed. This data set is analyzed to investigate the interannual variability of the major compounds in the wet savanna precipitation. This variability can be evaluated as a function of the amplitude of the main sources and the pluviometric regimes at the studied site.

It has been noticed that from one year to the next the dominant ions are the same over the eight-year period of rain collected at Lamto, i.e., ammonium followed by formate, calcium, nitrate, chloride and sulfate (Figure 3a), with variation of 9.7 and 22.9, 6.4 and 14, 6.8 and 12.4, 6.2 and 9.8, 5.8 and 8.1 and 5.3 and 8.2, respectively. We present in Figure 4(a-d) the variability, around the mean (19952002) as calculated in Section 3.2, by groups of elements, each representative of major source identified in the mean characteristics study of rainfall composition (Table I). We grouped for the marine contribution $\mathrm{ssNa}^{+}, \mathrm{ssCl}^{-}, \mathrm{ssMg}^{2+}$, identified 


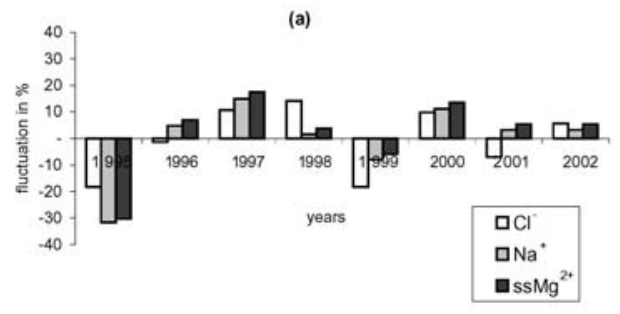

(c)

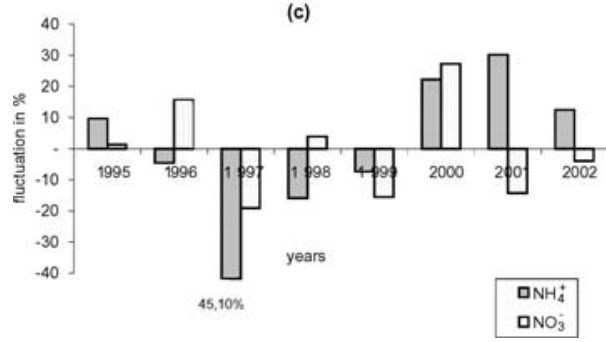

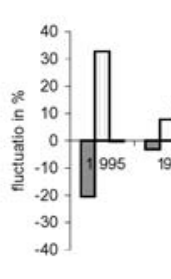

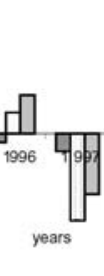

(b)

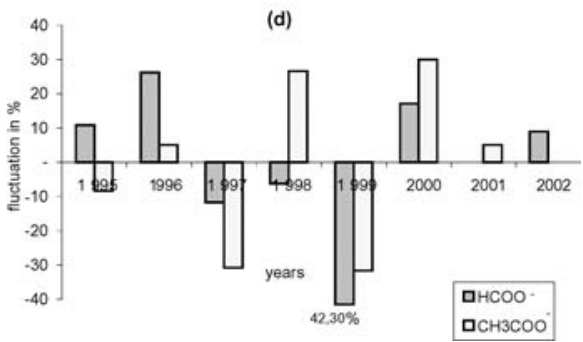

Figure 4. Interannual variability around the mean (1995-2002) of the Volume Weighted Mean (VWM) concentration in precipitation, by groups of elements, each representative of major source identified in the mean characteristics study of rainfall composition: 4(a) sea salt, 4(b) terrigeneous, 4(c) nitrogenous, 4(d) vegetation groups.

in Section 3.2, as major marine compounds (Figure 4a). $\mathrm{nssCa}^{2+}, \mathrm{nssMg}^{2+}$ and $\mathrm{nssSO}_{4}^{2-}$ will represent the terrigeneous contribution (Figure $4 \mathrm{~b}$ ), $\mathrm{NO}_{3}^{-}$and $\mathrm{NH}_{4}^{+}$ for the nitrogenous contribution (Figure $4 \mathrm{c}$ ), and the vegetation source by formate and acetate (Figure 4d). Calculation of contribution of sea salt (ss) particle in the dissolved phase is presented in Section 3.2.1.

The 8 years interannual variability (1995 to 2002) is displayed in Figure 4. The $\mathrm{Na}^{+}$and $\mathrm{Cl}^{-}$VWM vary from 4.3 to $7.2 \mu$ eq..$^{-1}$ and from 5.8 to 8.1 , respectively. These fluctuations are in the same direction with a deviation of $\pm 18 \%$. During 1995, we observe that VWM for marine species are very low implying a strong deficit around the mean (30\% and $18 \%$ for $\mathrm{Na}^{+}$and $\mathrm{Cl}^{-}$respectively). Except during 1995, all other years are within $10 \%$ of mean VWM (Figure 4a). The terrigeneous species vary from $\pm 30 \%$ around the mean VWM with a range of 6.8-12.4 $\mu$ eq..$^{-1}$ and 1.7-3.6 $\mu$ eq..$^{-1}$ for $\mathrm{nssCa}^{2+}$ and $\mathrm{nssMg}^{2+}$, respectively (Figure $4 \mathrm{~b}$ ). For the vegetation group, besides 1999, the VWM values are quite homogenous. The main organic ions, formate and acetate vary from 6.4 to $14 \mu$ eq. $1^{-1}$ and from 4.1 to $7.8 \mu$ eq. $1^{-1}$ respectively. $\mathrm{NH}_{4}^{+}$and $\mathrm{NO}_{3}^{-}$range is comprised between 9.7 and 22.9 $\mu$ eq. $1^{-1}$ and 6.2 to $8.1 \mu$ eq. $1^{-1}$ respectively. Ammonium which correspond mainly to a local source, presents higher fluctuations than $\mathrm{NO}_{3}^{-}$, with $\pm 35 \%$ for ammonia and $\pm 20 \%$ for nitrate. During 1997, all concentrations are very low for unknown reasons.

The year 1999 presents deficits for all elements, with a total annual load at 20\% less that the mean. Rainfall presented positive anomalies during that year $(17 \%$ 
increases with $1402.9 \mathrm{~mm}$ ) which diluted all chemical compounds. The largest deficits (30\% to $50 \%$ less in concentration), are for $\mathrm{Ca}^{2+}, \mathrm{Mg}^{2+}, \mathrm{K}^{+}, \mathrm{NH}_{4}^{+}, \mathrm{C}_{2} \mathrm{O}_{4}^{2-}$. The dry season was indeed shorter by two months. The rainy season ended late during November of 1998, while it started earlier in 1999. The level of aerosol emission from savanna fires and soils were then subsequently reduced.

\subsection{ANNUAL CHEMICAL COMPOSITION OF RAINWATER}

The yearly mean chemical characteristics of wet savanna rainfall at Lamto are analyzed and compared through correlation, to that from other sites, ecosystem and sources. In Table IV the mean annual VWM concentrations and the wet deposition for four IDAF sites are displayed: Lamto for the wet savanna, Banizoumbou for dry savanna, Zoetele and Petit Saut for the rainforest. Petit Saut located in the French Guyana rainforest is a reference site for forested ecosystem, with Amazonian atmospheric influences. Banizoumbou, Lamto, and Zoetele along the african transect: dry savanna- wet savanna-forest.

Correlation coefficients between the various chemical parameters will be examined in order to determine the potential sources that influence the rainwater composition, and/or potential origin of some of the components that are subsequently transported in the same air masses. Correlation coefficients using the "Spearman method", with a $1 \%$ confidence level, are displayed in Table V.

\subsubsection{The Marine Contribution}

Sodium chloride and potassium, magnesium and calcium salts are major chemical components or marine aerosols. Studies by Crozat in Côte d'Ivoire (Crozat, 1978). Have shown that $\mathrm{Na}$ and $\mathrm{Cl}$ have a main contribution to marine aerosols chemical composition. Sodium concentration in dissolved terrigeneous aerosol as quantified by Crozat (i.e., $\mathrm{Na} / \mathrm{Al}$ ratio of 0.09 ) is significant when compared to that of chlorine ( $\sim 100 \mathrm{ppm}$ in savanna soils). This is one of the reason we use $\mathrm{Cl}$ as a tracer for presence of marine environment in this study. The most common method of evaluating the contribution of sea salts to ion concentrations in precipitation, is then to compare the $\mathrm{Cl}^{-} / \mathrm{Na}^{+}$ratio in measured precipitation to that in seawater.

The annual VWM concentrations of sodium and chloride are equal to 6.3 and $7.1 \mu$ eq. $1^{-1}$, respectively (Table IV). These two components are highly correlated $(r=0.85)$ Table $\mathrm{V}$ and present a mean annual ratio of 1.1 closed to the sea water ratio (1.16) (Keene et al., 1986). These concentrations are representative of the marine influence that affects the Lamto site, located at about one hundred kilometers far from the coast. For comparison, the coastal site of Petit Saut in Amazonia has concentrations of $\mathrm{Na}^{+}$and $\mathrm{Cl}^{-}$four times higher than that in Lamto (Artaxo et al., 2003). In Zoétélé, located at $200 \mathrm{~km}$ from the Atlantic Ocean, concentrations falls to $4.0 \mu$ eq. $1^{-1}$ for $\mathrm{Na}^{+}$and $4.3 \mu$ eq..$^{-1}$ for $\mathrm{Cl}^{-}$(Sigha et al., 2003). In order to differentiate the marine contribution for each element, we calculated the part of 


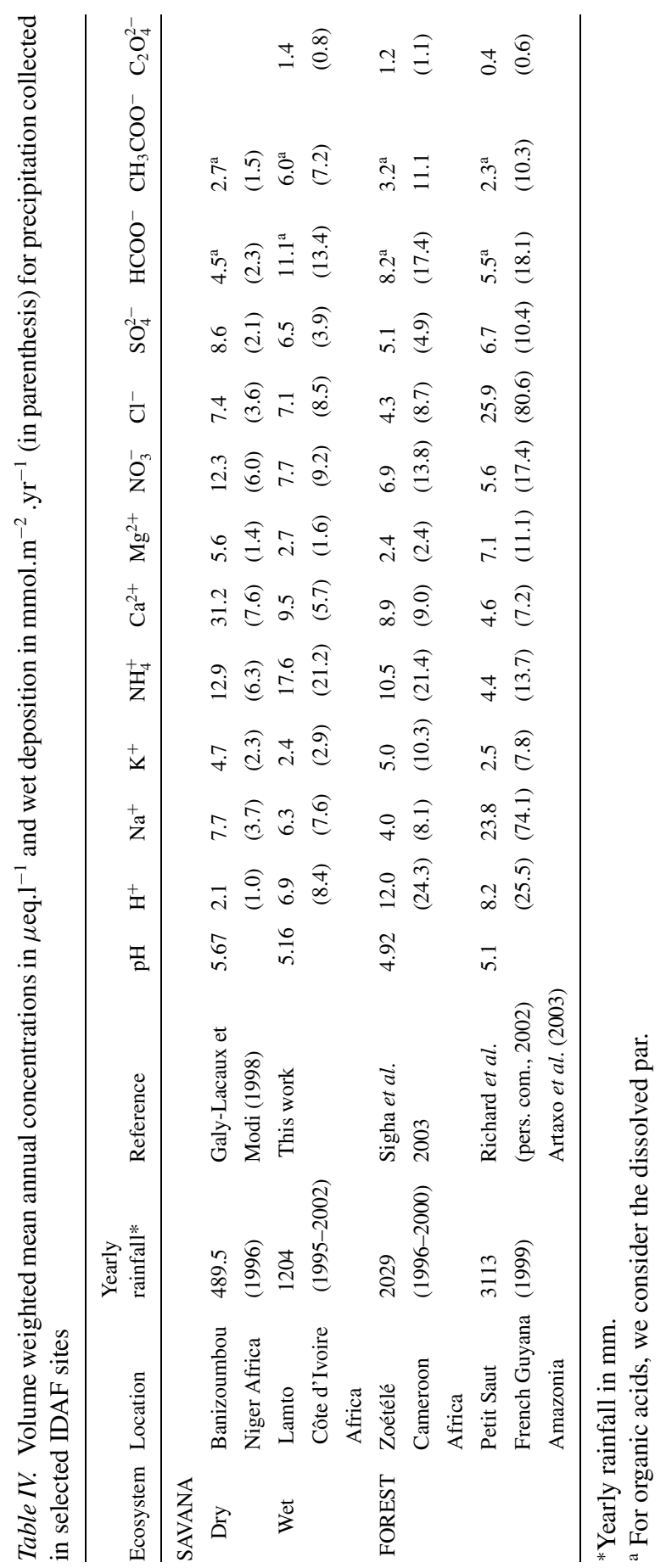




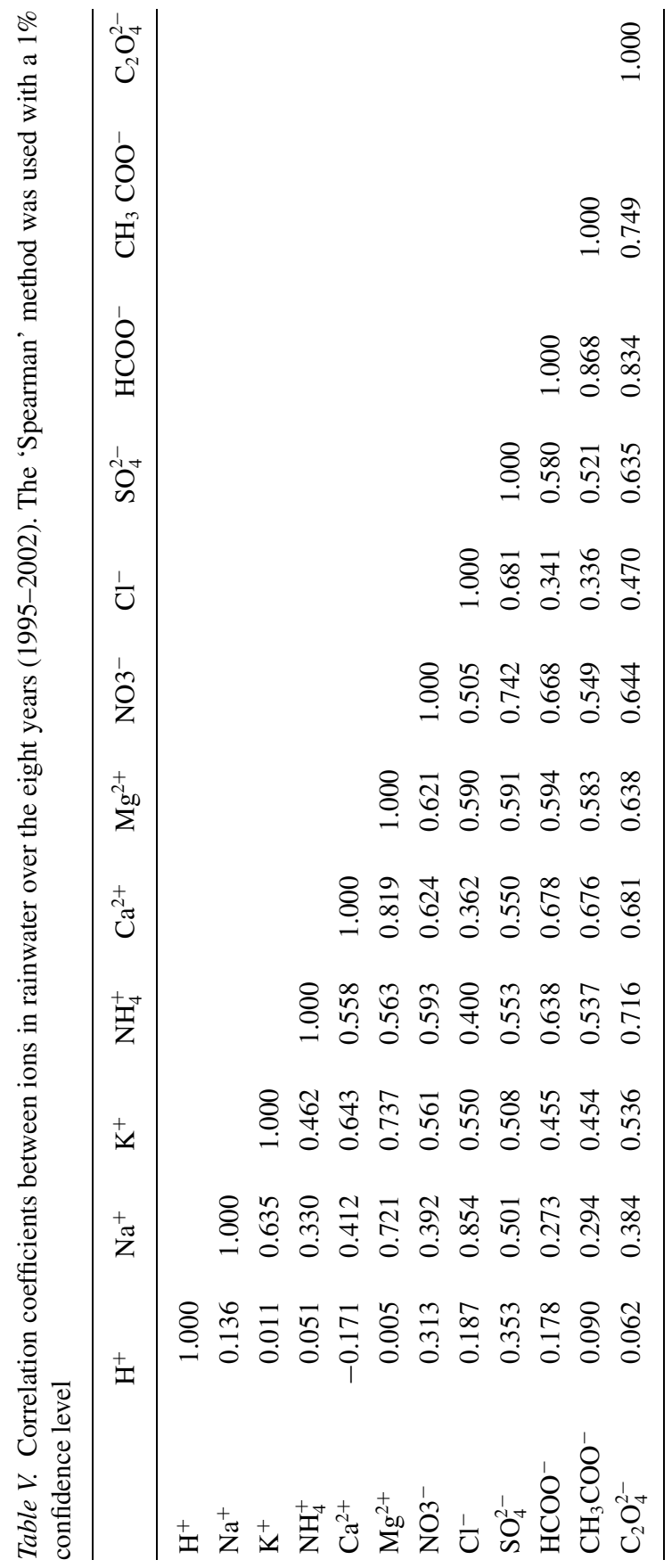


sea salt (ss) particles in the dissolved phase using $\mathrm{Cl}^{-} / \mathrm{Na}^{+}$ratio obtained from the following equation:

$$
[X]_{\text {marine }}=[\mathrm{Na}]_{\text {rain }} \times[X / \mathrm{Na}]_{\text {sea }}
$$

with $[X]_{\text {marine: }}$ : marine contribution for the element $X$ in $\mu$ eq. $1^{-1}$; $[\mathrm{Na}]_{\text {rain }}$ : sodium ion concentration in rainwater $\left(\mu\right.$ eq. $\left.1^{-1}\right) ;[X / \mathrm{Na}]_{\text {sea }}$ : concentration ratio in seawater after Keene et al. (1986).

Results from Lamto indicate that the marine contribution is high for chloride (99\%) and magnesium (54\%). The calculated correlation between $\mathrm{Mg}^{2+}$ and $\mathrm{Na}^{+}$ and between $\mathrm{Mg}^{2+}$ and $\mathrm{Ca}^{2+}$ are: $r=0.72$ and $r=0.82$, respectively. It shows that magnesium concentration has a double origin, i.e., marine and terrigeneous estimated at $54 \%$ and $46 \%$, respectively. The marine contribution for sulphate, potassium and calcium concentrations are 2.6 and $3 \%$, respectively.

\subsubsection{The Terrigeneous Contribution}

The annual non sea salt (nss) contributions in precipitation are evaluated at 9.2 $\mu$ eq. $\mathrm{l}^{-1}\left(\mathrm{nssCa}^{2+}\right), 5.7 \mu$ eq. $\mathrm{l}^{-1}\left(\mathrm{nssSO}_{4}^{2-}\right), 2.3 \mu$ eq. $\mathrm{l}^{-1}\left(\mathrm{nssK}^{+}\right)$and $1.3 \mu$ eq. $\mathrm{l}^{-1}$ $\left(\mathrm{nssMg}^{2+}\right)$. The multiple regression analysis gives correlation coefficient equal to $r=0.82$ for $\mathrm{Ca}^{2+}$ and $\mathrm{Mg}^{2+}, r=0.55$ for $\mathrm{Ca}^{2+}$ and $\mathrm{SO}_{4}^{2-}$ and $r=0.64$ for $\mathrm{Ca}^{2+}$ and $\mathrm{K}^{+}$(Table $\left.\mathrm{V}\right)$. These correlations indicate that the main terrigeneous ions were associated with the formation of eolian particles which include gypsum $\left(\mathrm{CaSO}_{4}\right)$, calcite $\left(\mathrm{CaCO}_{3}\right)$ and dolomite $\left(\mathrm{CaMg}\left(\mathrm{CO}_{3}\right)_{2}\right)$ (Bohn et al., 1985; Loÿe-Pilot et al., 1986; Galy-Lacaux and Modi, 1998). The origin of potassium ion in rainwater is from washout of desert aerosols (from soil wind erosion), aerosols from combustion (Yoboué, 1991; Andreae et al., 1988a), and biogenic aerosols (Crozat et al., 1978). Emission from sea surface, associated with that of $\mathrm{Cl}$ ion are much less.

The study of the terrigeneous species VWM concentrations along the transect dry savanna- wet savanna-forest shows us a negative gradient from north to south of western Africa (see Table IV). Non sea salt calcium concentrations, associated with dust emission, vary from $30.8 \mu$ eq..$^{-1}$ in dry savanna, to 9.2 in wet savanna and $8.7 \mu$ eq. $1^{-1}$ and $3.6 \mu$ eq..$^{-1}$ in forests. Non sea salt sulfate and magnesium concentrations display a similar gradient with 7.7 and $3.8 \mu$ eq. $1^{-1}$ in dry savanna, 5.7 and 1.3 in wet savanna and 4.6 and 1.5 in equatorial forests respectively. In Africa, the convective rainfall includes marine elements from the boundary layer and terrigeneous elements from layers above which include continental air masses. This is why these two chemical signatures are being found in rainfall, which include seasonal to interannual variability.

\subsubsection{The Nitrogenous Contribution}

Ammonium is the most abundant ion found in the rain samples. The $\mathrm{NH}_{4}^{+} \mathrm{VWM}$ $\left(17.6 \mu\right.$ eq..$\left.^{-1}\right)$ is the highest when compared to Banizoumbou samples from dry 
savanna $\left(10.9 \mu\right.$ eq. $\left.1^{-1}\right)$, Zoetele $\left(10.5 \mu\right.$ eq..$\left.^{-1}\right)$ and Petit Saut $\left(4.4 \mu\right.$ eq. $\left.1^{-1}\right)$ from equatorial forests. The ammonium content in precipitation results from incorporation in cloud and rain water of gaseous ammonia and particles containing $\mathrm{NH}_{4}^{+}$. Major sources of $\mathrm{NH}_{3}$ include bacterial decomposition of urea in animal excreta and emission by natural or fertilized soils (Schlesinger and Hartley, 1992). In tropical regions, another significant source of ammonia is produced by savanna fires and domestic fuelwood burning (Lobert et al., 1990; Delmas et al., 1995; Brocard et al., 1996). The ammonium content in precipitation originating from the particulate phase. Seinfeld (1986) reported that generally in the atmosphere ammonia occurs as $\left(\mathrm{NH}_{4}\right)_{2} \mathrm{SO}_{4}$ but it is also possible to found it in the form of $\mathrm{NH}_{4} \mathrm{NO}_{3}$ (Parmar et al., 2000). In the way, gaseous sulfuric and nitric acids can be partially neutralized by gaseous $\mathrm{NH}_{3}$ to form $\left(\mathrm{NH}_{4}\right)_{2} \mathrm{SO}_{4}$ and $\mathrm{NH}_{4} \mathrm{NO}_{3}$ particles. Significant correlation found between $\mathrm{NH}_{4}^{+}$and $\mathrm{NO}_{3}^{-}(r=0.59)$ and between $\mathrm{NH}_{4}^{+}$and $\mathrm{SO}_{4}^{2-}(r=0.55)$ confirms the fact that the above particles originate from similar processes. On the other hand, gaseous $\mathrm{NH}_{3}$ can be a significant contributor to the $\mathrm{NH}_{4}^{+}$content in the precipitation of Lamto. Ourabi's measurements show a mean annual concentration of $\mathrm{NH}_{3}$ equal to 5 ppb (Al-Ourabi, 2002). In Section 4.1, we will analyze specifically the relative contribution of particles and gases to the integrated chemical content of the studied precipitation. At the scale of the wet savanna of Lamto, that presents the highest ammonium concentration of all the western African ecosystems, we assume that it is representative of the signature of a combination of sources: domestic animals, agro-systems, domestic combustion and biomass burning.

Nitrate VWM in the rain samples of Lamto with $7.7 \mu$ eq. $1^{-1}$ is comparable to the african forest $\left(6.9 \mu\right.$ eq. $\left.1^{-1}\right)$. However, it is lower than in dry savanna $\left(12.3 \mu\right.$ eq..$\left.^{-1}\right)$. Nitrate concentration in precipitation is the final result, in atmospheric air and cloud water, of homogeneous and heterogeneous processes, and the collection of nitrogenous gases and particles. Nitric oxide (NO), in the non-burning season, is the major nitrogen compound released from savanna soils. Sodium chloride and potassium, magnesium and calcium salts are major chemical components or marine aerosols. Studies by Crozat in Côte d'Ivoire (Crozat, 1978) have shown that $\mathrm{Na}$ and $\mathrm{Cl}$ have a meanly contribution to marine aerosols chemical composition. Sodium concentration in dissolved terrigeneous aerosol as quantified by Crozat (i.e., $\mathrm{Na} / \mathrm{Al}$ ratio of 0.09$)$ is significant when compared to that of chlorine $(\sim 100$ ppm in savanna soils). This is one of the reason we use $\mathrm{Cl}$ as a tracer for presence of marine environment in this study. The most common method of evaluating the contribution of sea salts to ion concentrations in precipitation, is then to compare the $\mathrm{Cl}^{-} / \mathrm{Na}^{+}$ratio in measured precipitation to that in seawater.

A large fraction of the NO produced is oxidized in the atmosphere by photochemical reactions into $\mathrm{HNO}_{3}$ or organic nitrates. $\mathrm{HNO}_{3}$ is very soluble in water and is thus easily scavenged by clouds and rain. High precipitation nitrate levels measured in the dry savanna has been mainly attributed to local sources represented 
by animals and savanna soils strong emitters of Nitric Oxide (Jaegle et al., 2004; Serça et al., 1998). Lower nitrate levels in Lamto can be explained by low $\mathrm{NO}_{x}$ emissions fluxes as measured by Serça et al. (1998). Moreover, IDAF gaseous measurements integrated from 1998 to 2001 confirm this result. Mean annual $\mathrm{NO}_{2}$ concentrations are about $1.3 \mathrm{ppbv}$ in Lamto and $2.4 \mathrm{ppbv}$ in Banizoumbou (Niger) (Al-Ourabi, 2002; Jaegle et al., 2004).

The nitrate concentration, for the different ecosystems, show a similar gradient to that observed for the terrigeneous compounds. The significant correlations between $\mathrm{Mg}^{2+}$ and $\mathrm{NO}_{3}^{-}$and between $\mathrm{Ca}^{2+}$ and $\mathrm{NO}_{3}^{-}$, both equal to 0.62 , indicate potential heterogeneous and multiphase chemical processes occurring between alkaline dust and gaseous nitric acid (Dentener et al., 1996; Galy-Lacaux et al., 2001). In Section 4 , we will investigate the importance and the role of these heterogeneous processes on rain acidity.

\subsubsection{The Acidic Compounds}

The mean $\mathrm{pH}$, calculated from the VWM of $\mathrm{H}^{+}$ion, in the wet savanna of Lamto is of 5.16 corresponding to a VWM $\left(\mathrm{H}^{+}\right)$of $6.9 \mu$ eq. $1^{-1}$. It is recognized that in tropical zone, the rainfall acidity vary with season (Sigha et al., 2003; Mphepya et al., 2004). In the wet savanna of Lamto, $\mathrm{pH}$ in the dry season is equal to 5.0 and to 5.2 during the wet season. The mean $\mathrm{pH}$ value in the savanna is comprised between the acidic $\mathrm{pH}$ measured in the forest of Zoétélé (4.92) and the high $\mathrm{pH}$ measured in the dry savanna (5.67). A positive gradient for acidity is noticed along the transect dry savanna-wet savanna- equatorial forest.

Formate and acetate concentrations present a high correlation $(r=0.87)$. These two organic compounds are originating from the oxidation of volatile organic carbon (VOC) into aldehyde and acid (Graedel and Crutzen, 1993). Volatile organic carbon are emitted by the vegetation source, and by savanna burning during the dry season. This is corroborated by significant correlation between formate and acetate with $\mathrm{NO}_{3}^{-}(r=0.67$ and $r=0.55)$ and $\mathrm{NH}_{4}^{+}(r=0.64$ and $r=0.54)$ (see Table V).

The calculated contribution of the organic acidity $\left(\mathrm{HCOOH}, \mathrm{CH}_{3} \mathrm{COOH}\right.$, $\mathrm{CH}_{3} \mathrm{CH}_{2} \mathrm{COOH}$ ) is equal to $56 \%$. The contribution of mineral acidity, mainly related to the incorporation of $\mathrm{H}_{2} \mathrm{SO}_{4}$ and $\mathrm{HNO}_{3}$ is equal to $44 \%$ (Table VI). This equivalence is characteristic of the african rainwater collected in equatorial Africa (Sigha et al., 2003; Andreae et al., 1994; Lacaux et al., 1992; Ayers et al., 1988; Galloway et al., 1982). This contribution characteristic of dry savanna can be compared to that of african forests where the acidity contributed by organic acids (40-60\%) is equivalent to that of mineral acids (60-40\%). The Amazonian composition is very much different, with the dominance of organic acids that account for $80-90 \%$ of the total acidity. In Amersfoort, an industrial site in dry savanna (South Africa), organic acids contribute to only $16 \%$ of the total acidity (Mphepya et al., 2004). A 
Table VI. Relative contribution of organic and mineral acidity to the total acidity measured at Lamto

\begin{tabular}{lcl}
\hline Acidity & Concentration in $\mu$ eq..$^{-1}$ & Acidity (\%) \\
\hline Organic acidity & & \\
$\quad-\mathrm{HCOO}^{-}$ & 11.1 & 36 \\
$\quad-\mathrm{CH}_{3} \mathrm{COO}^{-}$ & 6.0 & 20 \\
Total & 17.1 & 56 \\
Mineral acidity & & \\
$-\mathrm{NO}_{3}^{-}$ & 7.7 & 25 \\
$-\mathrm{SO}_{4}^{2-}$ & 5.7 & 19 \\
Total & 13.4 & 44 \\
Total $\mathrm{H}^{+}$potential & 30.5 & \\
$\mathrm{H}^{+}$measured & 6.9 & \\
\hline
\end{tabular}

detailed study on acidity and its linkages with chemical, gaseous, and particulate composition in rainfall is presented in Section 4.

Acidic deposition, calculated from nitrate, sulfate, formate, and acetate concentrations, reaches 33.4 meq. $\mathrm{m}^{-2} \cdot \mathrm{yr}^{-1}$ in wet savanna. The Stockholm Environment Institute (SEI) has recently proposed a global assessment of terrestrial ecosystem sensitivity to acidic deposition (Cinderby et al., 1998). This assessment depends on the buffering capacity of the base saturation to identify soils that have high weathering rate and the cation exchange capacity to quantify the capacity of a soil to buffer acidity. A global map prepared by SEI, with five classes of sensitivity to acidic deposition, from a critical load of 200 meq. $\mathrm{m}^{-2} \cdot \mathrm{yr}^{-1}$ for the insensitive class to a critical load of 25 meq. $\mathrm{m}^{-2} \cdot \mathrm{yr}^{-1}$ for the most sensitive class. At Lamto, which belong to the most sensitive class, the measured acidic deposition of 33.4 meq. $\mathrm{m}^{-2} \cdot \mathrm{yr}^{-1}$ shows that a potential risk of acidification is important.

\subsection{MEAN SEASONAL CHEMICAL COMPOSITION}

In this section, the mean seasonal chemical composition of rainfall is studied. Wet seasonal deposition over wet savanna is also examined. This is to evaluate the seasonal relative contribution to total amounts and discriminate the various sources.

Referring to the seasonal rainfall distribution displayed in Table II, the mean seasonal VWM concentrations have been determined for dry and wet seasons (see Figure 5). During the 8 dry seasons, 74 samples out of 615 are used. During the dry season, the level of VWM concentration is about 2.5 times higher than that of wet season. The highest levels of VWM concentration were found in samples with strong signature of the terrigeneous and biomass burning sources. The ratio dry season/wet season varies from 2 to 3 . The ammonium concentration during 


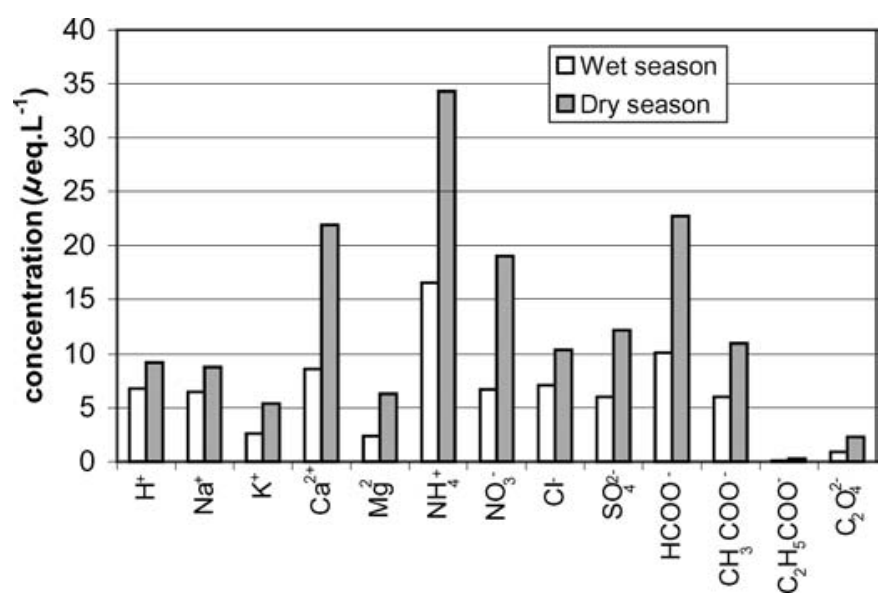

Figure 5. Seasonal Volume Weighted Mean (VWM) chemical composition of precipitation collected at Lamto (January 1995-December 2002).

the dry season remains the highest $\left(34.3 \mu\right.$ eq. $\left.1^{-1}\right)$, followed by that of formate (22.7 $\mu$ eq. $\left.1^{-1}\right)$, calcium $\left(21.9 \mu\right.$ eq. $\left.1^{-1}\right)$, nitrate $\left(19 \mu\right.$ eq. $\left.1^{-1}\right)$, sulfate $\left(12.2 \mu\right.$ eq. $\left.1^{-1}\right)$, and acetate $\left(11 \mu\right.$ eq..$\left.^{-1}\right)$. Also $70 \%$ of rain samples have less than $10 \mathrm{~mm}$ of rainfall. The weak enrichment factor of 1.35 for $\mathrm{Na}$ (from marine source) might be due to the dilution by the rainwater liquid content during the dry season. Since the enrichment factor from fires and terrigeneous sources is 2.4 for $\mathrm{NO}_{3}^{-}, \mathrm{K}^{+}, \mathrm{Ca}^{2+}, \mathrm{Mg}^{2+}, \mathrm{NH}_{4}^{+}$, we speculate that the latter emissions almost double during the dry season. This is corroborated at Lamto, where high gaseous concentrations are measured during the dry season: $4.2 \mathrm{ppbv}$ for nitrogen dioxide, $11.3 \mathrm{ppbv}$ for ammonia (Al-Ourabi, 2002). In spite of high VWM during dry seasons, the wet deposition is only $4 \%$ to $10 \%$ that of wet deposition, annually (Figure 5).

\subsection{ANNUAL WET DEPOSITION FLUXES}

The annual wet deposition depends both of the annual rainfall amount and the chemical content measured in the precipitation. Figure $3 \mathrm{~b}$ presents the wet deposition fluxes in mmol per year per squared meter by year. We notice that the global tendency of the total deposition of all the chemical species follows the same trends observed for the chemical concentration year by year. The total deposition varies in the range of 64 to $104 \mathrm{mmol} \cdot \mathrm{m}^{-2} \cdot \mathrm{yr}^{-1}$ with maximum deviation of $\pm 20 \%$ around the mean 90 mmol.m ${ }^{-2} \cdot \mathrm{yr}^{-1}$ (Figure 3b).

To investigate the wet deposition fluxes, it is important to note that fluxes were directly linked to the rainfall gradient in the semi-arid savanna of Niger, equatorial forests in Cameroon and in Amazonia with a range from 500 to 2000$3000 \mathrm{~mm} \cdot \mathrm{yr}^{-1}$. Lamto with a pluviometry of $1200 \mathrm{~mm} \cdot \mathrm{yr}^{-1}$ presents wet deposition of marine and terrigeneous elements such as $\mathrm{Ca}^{2+}, \mathrm{Mg}^{2+}, \mathrm{Cl}^{-}$and $\mathrm{SO}_{4}^{2-}$ 
(Table IV), within the same range than a forested ecosystem. Ammonium with $21.2 \mathrm{mmol} . \mathrm{m}^{-2} \cdot \mathrm{yr}^{-1}$ is the highest wet deposition flux and is similar to that from the equatorial forest and 3.5 times higher than that in Niger. Recently, results about the wet atmospheric nitrogen deposition in Africa have revealed that it was dominated by $\mathrm{NH}_{4}$, which accounts for about $60 \%$ of the total $\mathrm{N}$ flux (IGAC, 2003). In the wet savanna of Lamto, a total mean wet deposition of about $4.2 \mathrm{~kg} \mathrm{~N} / \mathrm{ha}$.yr have been recorded with $70 \%$ coming from $\mathrm{N}\left(\mathrm{NH}_{4}\right)$ and $30 \%$ of $\mathrm{N}\left(\mathrm{NO}_{3}\right)$. For nitrate deposition, the wet savanna with $9.2 \mathrm{mmol} \cdot \mathrm{m}^{-2} \cdot \mathrm{yr}^{-1}$ is in the average range measured from the dry savanna in the forest $\left(6.0-3.8 \mathrm{mmol} \cdot \mathrm{m}^{-2} \cdot \mathrm{yr}^{-1}\right)$. A gradient of $\mathrm{H}^{+}$deposition is measured with $1 \mathrm{mmol} . \mathrm{m}^{-2} \cdot \mathrm{yr}^{-1}$ in the dry savanna, 8.4 in the wet savanna, 24.3 in the African forest and 25.5 in the Amazonian forest. This gradient of acidity is correlated to the nitrate and the organic ions deposition gradients.

The above results underline the importance of terrigeneous source in a dry ecosystem when compared to African wet savanna and forest ecosystems. Conspicuous gradient of calcium, magnesium and sulfate VWM concentrations from Niger to Cameroon are noticed. The wet savanna is also characterized by a strong nitrogenous contribution especially in ammonium, the higher VWR concentrations of all the ecosystems. Also high VWR concentrations in organic ions are measured. These latter two contributions are explained by the simultaneous contribution of local sources (animals, agriculture) and regional and global sources such as biomass burning and terrigeneous sources. To finalize, the global analysis of the data base, seasonally and interanually, allows to characterize for the first time, the average chemical content and wet deposits in wet savanna, with $\pm 20 \%$ variations.

\section{Relative Contribution of Particles and Gases and Acidity in Precipitation}

\subsection{RELATIVE CONTRIBUTION OF PARTICLES AND GASES}

Heterogeneous chemistry processes, represented by the potential interactions between gases, water and particles, have a significant impact on the chemistry of the troposphere. In this context, mineral dust aerosols are important reactive surface for gaseous uptake $\left(\mathrm{SO}_{2}, \mathrm{NOy}\right.$, and $\left.\mathrm{O}_{3}\right)$. Smith and Chughtai (1995) have also demonstrated the importance of heterogeneous reactivity of black carbon with $\mathrm{H}_{2} \mathrm{O}, \mathrm{SO}_{2}$, $\mathrm{O}_{2}, \mathrm{HNO}_{3}$ and mineral particles interactions have been previously studied according field measurements in the Atlantic and Pacific Oceans (Savoie et al., 1989; Prospero et al., 1995), in wet savannas of Africa (Servant et al., 1984; Yoboué, 1991) and in Asian aerosol (Gao et al., 1991; Carmichaël et al., 1996, 1997). Moreover, recent modeling studies have included these $\mathrm{HNO}_{3}$ and mineral particles interactions (Dentener et al., 1996; Tbazaedeh et al., 1998). In Africa, an original study in the Sahelian region has been conducted through IDAF field measurements and SCAPE modeling simulations (Galy and Modi, 1998; Galy et al., 2001). The results of this study point out the major role of heterogeneous processes in the Sahelian region in regulating the acidity deposition. It allowed proposing a conceptual model of 
atmospheric chemistry representative of the chemical reactions of soil dust particles with water vapor, nitric acid and organic acid. Considering the importance of heterogeneous process in the tropical chemistry, in this section and from the measurements made at Lamto, Banizoumbou and Zoetele (IDAF sites), an estimation of the gaseous and the particulate phases contribution to the chemical content of the precipitation is given. Then, potential and measured acidity are compared and their relationship with the particulate phase and the associated heterogeneous processes.

To investigate the relative contribution of particles and gases in rainwater, we propose a new concept. PCrain is for relative particulate contribution, while GCrain stands for gaseous contribution gazeuse. The non volatile cations $\mathrm{Ca}^{2+}, \mathrm{Na}^{+}, \mathrm{Mg}^{2+}$ and $\mathrm{K}^{+}$are considered as representative of the mineral particulate phase. In order to apply the neutrality principle, the sum of the cations is equilibrated into an equivalent sum of anions. Thus particulate contribution is estimated by multiplying the cations sum by 2 . The PCrain contribution is then obtained from: PCrain $=2 \times\left(\mathrm{Ca}^{2+}+\right.$ $\left.\mathrm{Mg}^{2+}+\mathrm{K}^{+}+\mathrm{Na}^{+}\right) /(\Sigma \mathrm{AE}+\Sigma \mathrm{CE}) . \mathrm{AE}$ is the anions sum in $\mu$ eq. $\mathrm{l}^{-1}\left(\mathrm{Cl}^{-}+\mathrm{NO}_{3}^{-}\right.$ $\left.+\mathrm{SO}_{4}^{2-}+\mathrm{HCOO}^{-}+\mathrm{CH}_{3} \mathrm{COO}^{-}+\mathrm{C}_{2} \mathrm{H}_{5} \mathrm{COO}^{-}+\mathrm{HCO}^{-}\right)$and $\mathrm{CE}$ is the cations sum in $\mu$ eq. $\mathrm{l}^{-1}\left(\mathrm{H}^{+}+\mathrm{Ca}^{2+}+\mathrm{Na}^{+}+\mathrm{Mg}^{2+}+\mathrm{NH}_{4}^{+}+\mathrm{K}^{+}\right)$. The VWM carbonates implied in the computation are: $26.3 \mu$ eq. $1^{-1}$ for Banizoumbou, $20 \mu$ eq. $1^{-1}$ for Lamto, and $30.8 \mu$ eq. $1^{-1}$ for Zoetele. In our computation, PCrain does not take into account particulate originating from gaseous reaction (i.e., $\left.\mathrm{NH}_{4} \mathrm{NO}_{3},(\mathrm{NH} 4)_{2} \mathrm{SO}_{4}\right)$. As such the PCrain is underestimated. The gas contribution (GCrain) is defined by the difference 1-PCrain. Results of yearly PCrain and GCrain are presented in Figure 6. The relative contribution of gases and particles to the chemical content of the precipitation is $40 \%$ for particles and $60 \%$ for gases. The interannual variability is somewhat weak. Years 1995 and 1997 are extremes with $33 \%$ and $47 \%$ of particles contribution, respectively. Using the same concept in the two other IDAF sites, the gaseous and the particulate contributions have been calculated. In the dry savana

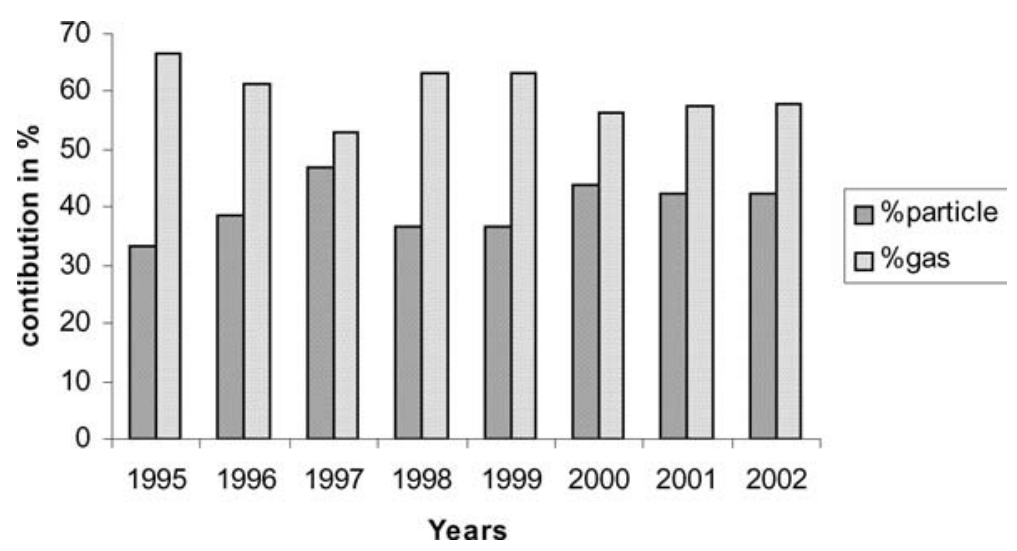

Figure 6. Yearly relative contribution of gases and particles to the total chemical content of the precipitation. 
of Banizoumbou, $80 \%$ is in the particulate phase and $20 \%$ is in the gas phase. To the opposite; in the forest of Zoetele $20 \%$ is in the particulate phase and $80 \%$ in the gas phase. The particle contribution decreases by $80 \%$ in dry savanna to $20 \%$ in forest. A $40 \%$ particle contribution is found in wet savanna. This is consistent with the high dust emissions from the Sahel, and the progressive washout of particles along the transect.

\subsection{RAIN ACIDITY AT LAMTO}

Sigha et al. (2003) have defined potential acidity (pA) for Zoetele rainfall as the sum in nitrate, sulfate, formate and acetate concentration, considering that all ions are associated with $\mathrm{H}^{+}$. If computed from the same manner the Lamto pA is of 30.5 $\mu$ eq. $1^{-1}$. The measured acidity (mA) for Lamto is $6.9 \mu$ eq. $1^{-1}$ (Table VI). So, 23.6 $\mu$ eq. $1^{-1}$ of $\mathrm{H}^{+}$have been neutralized. According to recent rain chemistry studies in West Africa, one of the major neutralization mechanisms is the uptake of strong acid gases by soil dust particles (Galy-Lacaux et al., 2001; Sigha et al., 2002). In particular, dust alkaline particles favors the uptake of $\mathrm{HNO}_{3}$. Alkalinity in soil particles is to a large part determined by the $\mathrm{CaCO}_{3}$ content. Our results point out that this is a key process in the wet savanna of Lamto. On one hand, we determine a significant correlation $(r=0.62)$ between calcium and nitrate in Lamto precipitation. Moreover, Lamto measurements of aerosol chemical composition as a function of granulometric spectra clearly indicate that $\mathrm{NO}_{3}^{-}$is captured by terrigeneous coarse particles mainly formed by calcium and magnesium (Yoboué, 1991).

To illustrate the heterogenous chemical interactions all over the west central african transect (dry savana, humid savana, equatorial forest), the calcium concentration versus the difference between the potential acidity (pA) and the measured acidity (mA) for the precipitation of three IDAF sites is presented in Figure 7. For

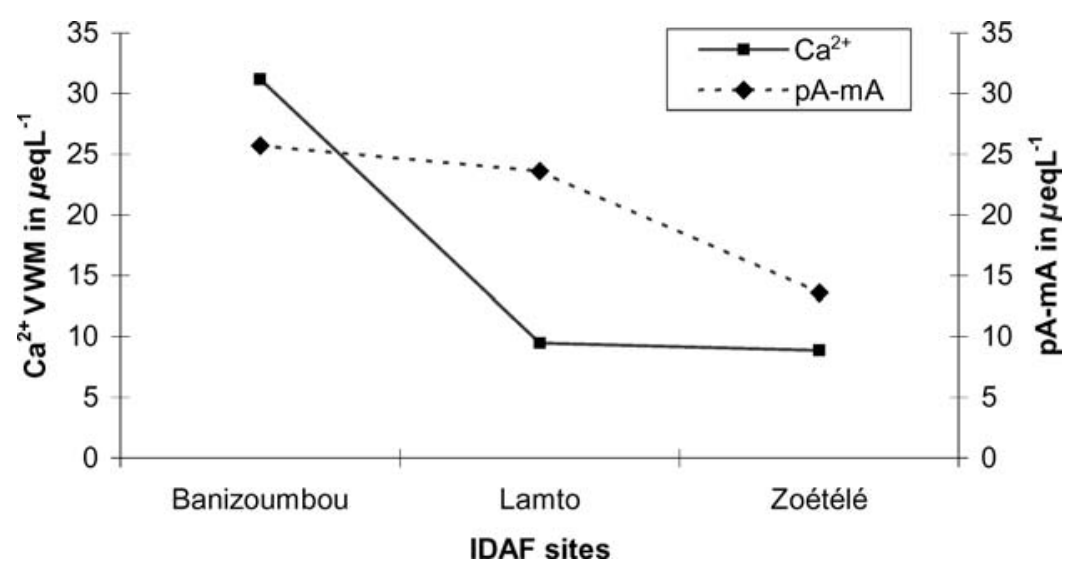

Figure 7. Calcium concentration versus the difference (pA-mA) between the potential acidity $(\mathrm{mA})$ for the precipitation of 3 IDAF sites. 
Banizoumbou in Niger, Figure 7 shows that the neutralization of $\mathrm{HNO}_{3}$ is completed by the dust calcium content as Galy et al. (2001) have already demonstrated. In Lamto, the calcium content can only explain $40 \%$ of the neutralized acidity. This result is consistent with EXPRESSO measurements over the wet savanna of Central Africa Republic (Galy et al., 2001; Ruellan et al., 1999). In both sites, our results confirm the existence of heterogeneous processes between mineral aerosols and nitrogenous compounds. In Zoetele (Cameroon), the calcium content can only explain $65 \%$ of the neutralized acidity. To explain the remaining acidity in Lamto, we hypothetize that the direct absorption of gaseous $\mathrm{NH}_{3}$ by the cloud droplets and raindrops has to be taken into account. This hypothesis is confirmed by the highest ammonium concentrations in Lamto rain water $\left(17.6 \mu\right.$ eq. $\left.1^{-1}\right)$. $\mathrm{NH}_{3}$ IDAF gas measurements in Lamto presents an annual mean of 5 ppbv. Other heterogeneous mechanisms must imply alkaline particles with $\mathrm{Mg}^{2+}, \mathrm{K}^{+}$among others and can contribute to neutralization of acid rain in wet savanna and forest.

\section{Conclusion}

In this paper, new results from a study on rainfall chemistry at the Lamto site (Côte d'Ivoire), representative of a wet savanna are presented. Results are to be associated with those from the IDAF programme over West Africa, at Banizoumbou (dry savanna, Niger) and at Zoetele (equatorial forest, Cameroon).

The rainfall mean chemical content at Lamto is computed on seasonal, interannual time scales and for the full 1995-2002 period. Interannual variability of the wet deposit is $\sim 20 \%$, associated to variability of atmospheric sources and rainfall amounts. Chemical signatures from gas and particles over West Africa are present at Lamto. Concentration of marine ions $\left(\mathrm{Na}^{+}, \mathrm{Cl}^{-}, \mathrm{Mg}^{2+}\right)$ is comparable to that obtained from other sites away from the Ocean. Ammonium with a VWM of $17.6 \mu \mathrm{eq} .1^{-1}$ is the most abundant, representing the $\mathrm{NH}_{3}$ source, and attributed to domestic animal wastes. $70 \%$ of the total nitrate settling $\left(4.2 \mathrm{~kg} \cdot \mathrm{ha}^{-1} \cdot \mathrm{yr}^{-1}\right)$ is from $\mathrm{NH}_{4}$. Rainfall concentration of $\mathrm{nssCa}^{2+}, \mathrm{nssSO}_{4}^{2-}, \mathrm{nssK}^{+}$, and $\mathrm{nssMg}^{2+}$ are linked to terrigeneous sources from wind erosion of Sahara-Sahelo soils. Particles embedded in air masses are then carried away by the Harmattan, and slowly washed down, from the dry savanna to the wet savanna and equatorial forest. The negative concentration gradient for $\mathrm{nssCa}^{2+}$ goes from $30.8 \mu$ eq. $\mathrm{l}^{-1}$ in dry savanna to $9.2 \mu \mathrm{eq} . \mathrm{l}^{-1}$ in wet savanna at Lamto and $8.9 \mu \mathrm{eq} . \mathrm{l}^{-1}$ in the Cameroon forest. A similar gradient is also obtained from mineral particles raifall content with concentration of $80 \%$ in dry savanna, $40 \%$ in wet savanna, and $20 \%$ in equatorial forest. The latter emphasize the importance of multiphases processes between gases and particles in West African ecosystems. In particular, the classic acid gas-particles chemistry explains the acid rain and its gradient along the transect dry savanna, wet savanna and equatorial forest. The weak acidity of $2.1 \mu \mathrm{eq} . \mathrm{l}^{-1}$ in dry savanna, is due to neutralization of gaseous nitric acid by alkaline particles (Galy and Modi, 1998). The measured acidity at Lamto $\left(6.9 \mu \mathrm{eq} . \mathrm{l}^{-1}\right)$ requires, when compared to a 
potential acidity of $30.5 \mu$ eq. $1^{-1}$, the neutralization of $23.6 \mu$ eq. $1^{-1}$ of acidity. This is accomplished at the $40 \%$ level by gas-particles interactions and by absorption of $\mathrm{NH}_{3}$ in the clouds liquid phase (60\%), as shown by the analyses of rainfall content.

The rainfall chemistry, quality-controlled from the IDAF network over West Africa has allowed to characterize multiphases chemistry, as a function of seasonal and interannual variability, and to estimate the critical wet deposition processes for proper functioning of African ecosystems. In the near future, maintenance of the IDAF measuring network, will allow to complete quantification of gaseous and particles dry deposition. In the longer term, study of total deposits (dry and wet) from long time series, will permit to analyze the slow temporal evolution of tropospheric chemistry, linked to climate variability and anthropogenic actions on tropical ecosystems.

\section{Acknowledgements}

We are grateful to the team of the Lamto station for the sampling, E. Gardrat from the 'Laboratoire d'Aérologie' in Toulouse for the chemical analysis. We also thank Y. M. Tourre from Medias-France for proofreading the manuscript. This work has been supported by the 'Institut National des Sciences de l'Univers' within the framework of the ORE programme (Observatoire de Recherché en Environnement). This work is part of the IDAF project (IGAC DEBITS AFRICA).

\section{References}

Al-Ourabi, H., 2002: Etude expérimentale de gaz azoté, du dioxyde de soufre et de l'ozone à l'échelle des écosystèmes de l'Afrique tropicale: Application à l'estimation des dépôts secs gazeux dans le cadre du réseau IDAF, Thesis, Université Paul Sabatier de Toulouse, Toulouse, France.

Andrea, M.O., 1994: Climate effects of changing levels, in World survey of climatology, 20, in future climate of the world, edited by A. Henderson-Sellers, p. 135.

Andreae, M. O., Browell, E. V., Garstang, M., Gregory, G. L., Harris, R. C., Hill, G. F., Jacob, D. J., Pereia, M. C., Sachse, G. W., Setze, A. S., Silva Dias, P. L., Talbot, R. W., Torres, A. L., and Wofsy, S. C., 1988a: Biomass burning emission and associated haze layers over Amazonia. $J$. Geophys. Res. 93, 1509-1527.

Artaxo, P., Lara, Luciene, L., Pauliquevis, Theotonio M., and Richard, S., 2003: Dry and Wet deposition in Amazonia, J. Geophys. Res. 95, 16987-16999.

Ayers, G. P. and Gillett, R. W., 1988: Acidification in Australia, in H. Rodhe and R. Herrera (eds.), Acidification in Tropical Countries, John Wiley, New York, pp. 347-402.

Baudet, J. G. R., Lacaux, J. P., Bertrand, J. J., Desalmand, F., Servant, J., and Yoboué, V., 1990: Presence of an atmospheric oxalate source in the intertropical zone. Its potential action in the atmosphere. Atmos. Res. 25, 465-477.

Bohn, L., McNeal, B. L., and Connor, G, A., 1985: Soil Chemistry, John Wiley, New York.

Brocard, D., Lacaux C., Lacaux, J. P., Kouadio, G., and Yoboué, V., 1996: Emissions from the combustion of biofuels in western Africa, in J. S. Levine (ed.), Global Biomass Burning, MIT Press, Cambridge.

Carmichaël, G. R., Zhang, Y., Chen, L. L., Hong, M. S., and Ueda, H., 1996: Seasonnal variation of aerosol composition at Cheju Island, Korea, Atmospheric Environment 30, 2407-2416. 
Carmichaël, G. R., Hong, M. S., Ueda, H., Chen, L. L., Murano, K., Park, J.K., Kang, C., and Shim, S., 1997: Aerosol composition at Cheju Island, Korea, J. Geophysical Research 102, 6047-6061.

Cinderby, S., Cambridge, H. M., Herrera, R., Hicks, W. K., Kuylenstierna, J. C. I., Murray, F., and Olbrich, K., 1998: Global assessment of ecosystem sensitivity to acid deposition, SEI edition, pp. $1-18$.

Crozat, G., 1978: l'aérosol atmosphérique en milieu naturel. Etude des différentes sources de potassium en Afrique de l'Ouest (C.I). Thèse de Doctorat ès sciences no. 844, Université Paul Sabatier, Toulouse.

DECAFE, Speciai Issue., 1991: J. Atmospheric Chemistry 22.

Delmas, R. and Servant, J., 1987: Echanges biosphère-atmosphère d'azote et de soufre en zone intertropicale. Transferts entre les écosystèmes forêt et savane en Afrique de l'Ouest, Atmos. Res. 21, 53-74.

Delmas, R., Lacaux, J. P., Menaut, J. C., Abbadie, L., Leroux, X., Helas, G., and Lobert, J., 1995: Nitrogen compound emission from biomass burning in tropical African savanna, FOS/DECAFE Experiment, J. Atmos. Chem. 22, 175-194.

Dentener, F. J., Carmichael, G. R., Zhang, Lelieved, Y. J., and Crutzen, P. J., 1996: Role of mineral aerosol as a reactive surface in the global troposphere, J. Geophys. Res. 101, 22869-22889.

EPA, 1994: Quality assurance Handbook for Air Pollution Measurement Systems, EPA/600R94/038e, United States Environment Protection Agency, Office of Research and Development, Washington.

Galloway, J. N., Likens, G. E., Keene, W. C., and Miller, J. M., 1982: The composition of precipitation in remote areas of the world, J. Geophys. Res. 87, 8771-8786.

Galy-Lacaux, C. and Modi, A. I., 1998 : Precipitation Chemistry in the Sahelian Savanna of Niger, Africa, J. Atmos. Chem. 30, 319-343.

Galy-Lacaux, C., Carmichael, G. R., Song, C. H., Lacaux, J. P., Al Ourabi, H., and Modi, A. I., 2001: Heterogeneous processes involving nitrogenous compounds and Saharan dust inferred from measurements and model calculations, J. Geophys. Res. 106, 12,559-12,578.

Gao, W., Wesely, M. L., and Lee, I. Y., 1991: A numerical study of the effects of air chemistry on fluxes of NO2, NO2, and O3 near the surface, J. Geophysical Research 96, 18761-18769.

Gautier, L., 1990: Contact forêt-savane en Côte d'Ivoire centrale: évolutionde la surface forestière de la reserve de Lamto (sud du V-Baoulé.) Candoella, 45, 627-641.

Graedel, T. E. and Crutzen, P. J., 1993: Atmospheric Change: An Earth System Perspective, W. H. Freeman and Company, New York, 446 pp.

IGAC, 2003: Atmospherc chemistry in a changing word, An Integration and Synthesis of Decade of Tropospheric chemistry Research, Series: Global Change-The IGBP Series, Brasseur, Guy P., Prinn, Ronald, G., Pszenny, Alexander, A. P. (eds.), Issue XIV, 300 p. 131 illus., Hardcover. W. H. Freeman and Company, New York, 446 pp.

IGAC, 2003: Atmospherc chemistry in a changing word, An Integration and Synthesis of Decade of Tropospheric chemistry Research, Series: Global Change-The IGBP Series, Brasseur, Guy P., Prinn, Ronald, G., Pszenny, Alexander, A. P. (eds.), Issue XIV, 300 p. 131 illus., Hardcover

IGACtivities Newsletter of the International Global Atmospheric Chemistry Project, DEBITS Special Issue no. 27 and 28, 2003.

Jaegle, L., Martin, R. V., Chance, K., Steinberger, L., Kurosu, T. P., Jacb, D, J., Modi, A. I., Yoboué, V., Sigha-Nkandjou, L., and Galy-Lacaux, C., 2004: Satellite maping of rain-induced nitric oxide emissions from soils, In preparation for Journal of Geophysical Research-Atmospheres.

Keene, W. C., Pszenny, A. A., Galloway, J. N., and Hartley, M. E., 1986: Sea-salt corrections and interpretation of constituent ratios in marine precipitation, J. Geophys. Res. 91, 6647-6658.

Kouadio, Y. K., OCHOU, D.A., and Servain, J., 2002: Tropical Atlantic and Rainfall Variability in Côte d'Ivoire, Geophysical Research Letters. 
Lacaux, J. P., Delmas, R., Kouadio, G., Cros, B., and Andreae, M.O., 1992: Precipitation chemistry in the Mayombe forest of equatorial Africa, J. Geophys. Res. 97, 6195-6206.

Lobert, J. M., Scharffe, D. H., Hao, W. M., and Crutzen, P. J., 1990: Importance of biomass burning in the atmospheric budgets of nitrogen containing gases, Nature 346, 552-554.

Loÿe-Pilot, M. D., Martin, M., and Morelli, J., 1986: Influence of Saharan dust on the acidity and atmospheric input to the Mediterranean, Nature 321, 427-728.

Mphepya, J. N., Pienaar, J. J., Galy-Lacaux, C., Held, G., and Turner, C.R., 2004: Precipitation chemistry in semi-Arid Areas of Southern Africa: A Case Study of a Rural and an industrial Site, J. Atmos. Chem. 47, 1-24.

Parmar, R. S., Satsangi, G. S., Lakhani, A., Srivastava, S. S., Prakash, S., Rastogi, R. K., Ramkumar, K. L., Venugopal, V., and Manohar, S. B., 2000: Diurnal and season behaviour of atmospheric ammonia and nitric acid in a suburban site, Proceedings of the 10th National Symposium on Environment-Pollution in Urban Environment, pp. 66-70.

Prospero, J. M., Schmitt R., Cuevas E., Savoie, D., Graustein, W., Turkenian K., Volz-Thomas, A., Oltmans, S., Levy, H., and Diaz, A., 1995: Temporal variability of ozone and aerosols in the free troposphere over the eastern North atlantic, Geophys. Res. Lett. 22, 2925-2928.

Ruellan, S., Cachier, H., Gaudichet. A., Maesclet, P., and Lacaux, J. P., 1999: Airborne aerosols over Central Africa during the EXPRESSO experiment, J. Geophys. Res. 104, 30673-30690.

Sanhueza, E., Hao, W. M., Scharffe, D., Donoso, L., and Crutzen, P. J., 1990: $\mathrm{N}_{2} \mathrm{O}$ and NO emission from soils of the northern part of the Guyana Schield, Venzuela, J. Geophys. Res. 95, 22, 481-22, 488.

Savoie D. L., Prospero J. M., and Saltzman, E. S., 1989: Non sea salt sulfate and nitrate in trade wind aerosols at Barbados: evidence for long range transport, J. Geophys. Res. 94, 5069-5080.

Seinfeld, J. H., 1986: Atmospheric Chemistry and Physics of Air Pollution, Wiley, New York.

Schlesinger, W. H. and Hartley, A. E., 1992: A global budget for atmospheric $\mathrm{NH}_{3}$, Biogeochemistry 15, 191-211.

Serça, D., Delmas, R., Le Roux, X., Parsons, D. A. B., Scholes, M. C., Abbadie, L., Lensi, R., and Labroue, L., 1998: Comparison and influence of season and fire, of nitrogen monoxide emissions from several African tropical ecosystems, Global Biogeochem. Cycles, 12, 637-651.

Servant, J., Delmas, R., Rancher, J., and Rodriguez, R., 1984: Aspects of the cycle of inorganic nitrogen compounds in the tropical rain forest of the Ivory Coast. J. Atmos. Chem. 1, 391-401.

Sigha-Nkamdjou L., Galy-Lacaux, C., Pont, V., Richard, S., Sighoumnou, D., and Lacaux, J. P., 2003: Rainwater chemistry and wet deposition over the equatorial forested ecosystem of Zoétélé(Cameroon), Journal of Atmospheric Chemistry 46, 173-198.

Smith, D. M. and Chughtai, A. R., 1995: The surface structure and reactivity of black carbon, Colloids Surfaces A, Physicochem. Eng. Aspects 105, 47-77.

Tbazaedeh, A., Jacobson, M. Z., Singh, H. B., Toon, O. B., Linn, J. S., Chatfield, R. B., Thakur, A. N., Talbot, R. W., and Dibb, J. E., 1998: Nitric acid scavenging by mineral and biomass burning aerosols, Geophys. Res. Lett. 25, 4185-4188.

Yoboué, V., 1991: Caractéristiques physiques et chimiques des aérosols et des pluies collectés dans la savane humide de Côte d'Ivoire, Th. Doc. № 914, Uni. Paul Sabatier, Toulouse. 